Supplementary materials

\title{
Modeling the Size Distribution and Chemical Composition of Secondary Organic Aerosols during the Reactive Uptake of Isoprene-Derived Epoxydiols Under Low Humidity Condition
}

Mega Octaviani ${ }^{1, \dagger}$, Manish Shrivastava ${ }^{1, *}$, Rahul A. Zaveri ${ }^{1}$, Alla Zelenyuk ${ }^{1}$, Yue Zhang ${ }^{2,3}$, Quazi Z. Rasool ${ }^{1}$, David M. Bell ${ }^{4}$, Matthieu Riva ${ }^{5}$, Marianne Glasius ${ }^{6}$, Jason D. Surratt ${ }^{3,7}$

${ }^{1}$ Pacific Northwest National Laboratory, Richland, Washington 99352 United States

${ }^{2}$ Department of Atmospheric Sciences, Texas A\&M University, College Station, Texas 77843 United States

${ }^{3}$ Department of Environmental Sciences and Engineering, Gillings School of Global Public Health, University of North Carolina at Chapel Hill, Chapel Hill, North Carolina 27599, United States

${ }^{4}$ Laboratory of Atmospheric Chemistry, Paul Scherrer Institute, Villigen 5232, Switzerland ${ }^{5}$ Univ. Lyon, Université Claude Bernard Lyon 1, CNRS, IRCELYON, 69626, Villeurbanne, France

${ }^{6}$ Department of Chemistry, Aarhus University, Aarhus C, 8000, Denmark

${ }^{7}$ Department of Chemistry, College of Arts and Sciences, University of North Carolina at Chapel Hill, Chapel Hill, North Carolina 27599 United States

†Present address: Institute of Meteorology and Climate Research (IMK-TRO), Department Troposphere Research, Karlsruhe Institute of Technology (KIT), Karlsruhe, Germany 
*Correspondence to manishkumar.shrivastava@pnnl.gov

Submitted to ACS Earth and Space Chemistry

This supporting information contains 10 pages with 1 table and 6 figures. 


\section{S.1 Methods}

\section{a) Chamber experiment}

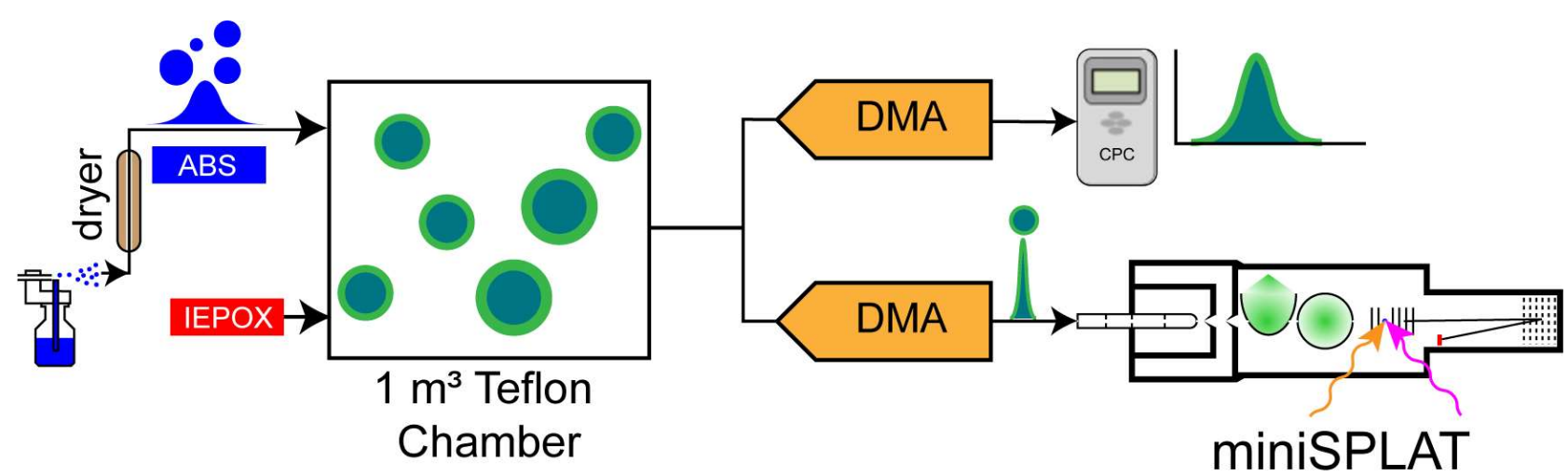

Figure S1. Schematic of the chamber experimental setup implemented in Riva et al. ${ }^{1}$ for the study of IEPOX multiphase chemistry.

\section{b) Particle-phase pseudo-first reaction rate constant $\left(k_{\mathrm{aq}}\right)$}

We computed the effective first-order rate constant $\left(k_{\mathrm{aq}}\right)$ defined in Eq. 1 and applied in Budisulistiorini et al. ${ }^{2}$ The rate constants are given in Table S1.

$$
\begin{aligned}
k_{\mathrm{aq}}= & k_{\mathrm{H}^{+}, \text {water }} a_{\mathrm{H}^{+}} \mathrm{LWC}_{\text {inorg }}+k_{\mathrm{HSO}_{4}^{-}, \text {water }}\left[\mathrm{HSO}_{4}^{-}\right] \mathrm{LWC}_{\text {inorg }} \\
& +k_{\mathrm{NH}_{4}^{+}, \text {water }}\left[\mathrm{NH}_{4}^{+}\right] \mathrm{LWC}_{\text {inorg }}+k_{\mathrm{H}^{+}, \mathrm{SO}_{4}^{2-}} a_{\mathrm{H}^{+}}\left[\mathrm{SO}^{2-}\right]
\end{aligned}
$$

where $a_{\mathrm{H}^{+}}$is the hydrogen ion activity that represents aerosol acidity, $\left[\mathrm{SO}_{4}^{2-}\right],\left[\mathrm{HSO}_{4}^{-}\right],\left[\mathrm{NH}_{4}^{+}\right]$are the concentrations of sulfate, bisulfate and ammonium ( $\mathrm{mol} \mathrm{L}^{-1}$ of aerosols), respectively, and $\mathrm{LWC}_{\text {inorg }}$ is the aerosol water content associated with the inorganic phase ( $\mathrm{mol} \mathrm{L}^{-1}$ of aerosols). The $\mathrm{H}^{+}$activity is defined as $\mathrm{H}^{+}$activity coefficient, as computed according to Zaveri et al. ${ }^{3}$, 
multiplied by the $\mathrm{H}^{+}$concentration. We applied appropriate $\mathrm{H}^{+}$activity coefficient correction at low RH based on comparisons between MOSAIC ${ }^{4}$ and E-AIM ${ }^{5}$ models.

IEPOX-SOA speciation is determined using OS branching ratio $(\beta)$ expressed by

$$
\beta=\frac{k_{\mathrm{H}^{+}, \mathrm{SO}_{4}^{2-}} a_{\mathrm{H}^{+}}\left[\mathrm{SO}^{2-}\right]}{k_{\mathrm{aq}}}
$$

Table S1. Third-order rate constants used to calculate $k_{\mathrm{aq}}$ in Eq. 1

\begin{tabular}{ccccc}
\hline SOA product & $\begin{array}{c}\text { nucleophile } \\
\text { added }\end{array}$ & $\boldsymbol{k}_{\mathrm{H}^{+}, \boldsymbol{i}}\left[\mathrm{M}^{-2} \mathrm{~s}^{-1}\right]$ & $\boldsymbol{k}_{\mathrm{HSO}^{-}, \boldsymbol{i}}\left[\mathrm{M}^{-2} \mathrm{~s}^{-1}\right]$ & $\boldsymbol{k}_{\mathrm{NH}^{+}, \boldsymbol{i}}\left[\mathrm{M}^{-2} \mathrm{~s}^{-1}\right]$ \\
\hline 2-methyltetrols & water & $9.00 \mathrm{E}-4^{\mathrm{a}}$ & $1.31 \mathrm{E}-5^{\mathrm{a}}$ & $3.10 \mathrm{E}-7^{\mathrm{b}}$ \\
IEPOX-organosulfates & sulfate & $1.27 \mathrm{E}-3^{\mathrm{c}}$ & & \\
\hline
\end{tabular}

${ }^{a}$ Eddingsaas et al. ${ }^{6} ;{ }^{b}$ Nguyen et al. ${ }^{7} ;{ }^{c}$ Riedel et al. ${ }^{8}$ 
c) Selecting $H_{\text {org }} D_{\text {org }}$ and $H_{\text {aq }}$ parameters

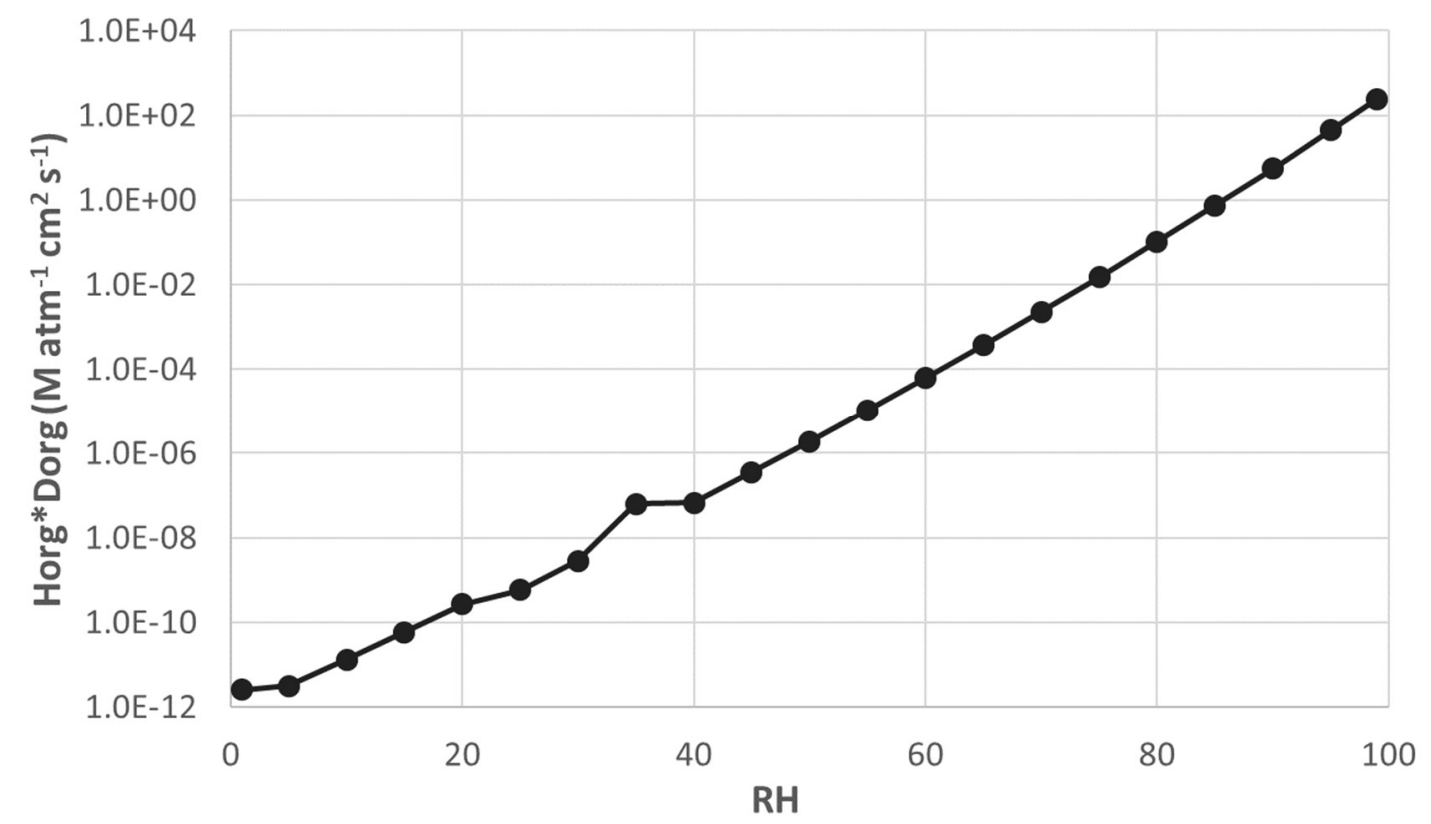

Figure S2. Experimentally measured and extrapolated Henry's Law and diffusion coefficients $H_{\mathrm{org}} D_{\mathrm{org}}\left(\mathrm{M} \mathrm{atm}^{-1} \mathrm{~cm}^{2} \mathrm{~s}^{-1}\right)$ of IEPOX in the organic layer under different relative humidity $(\%)$. 


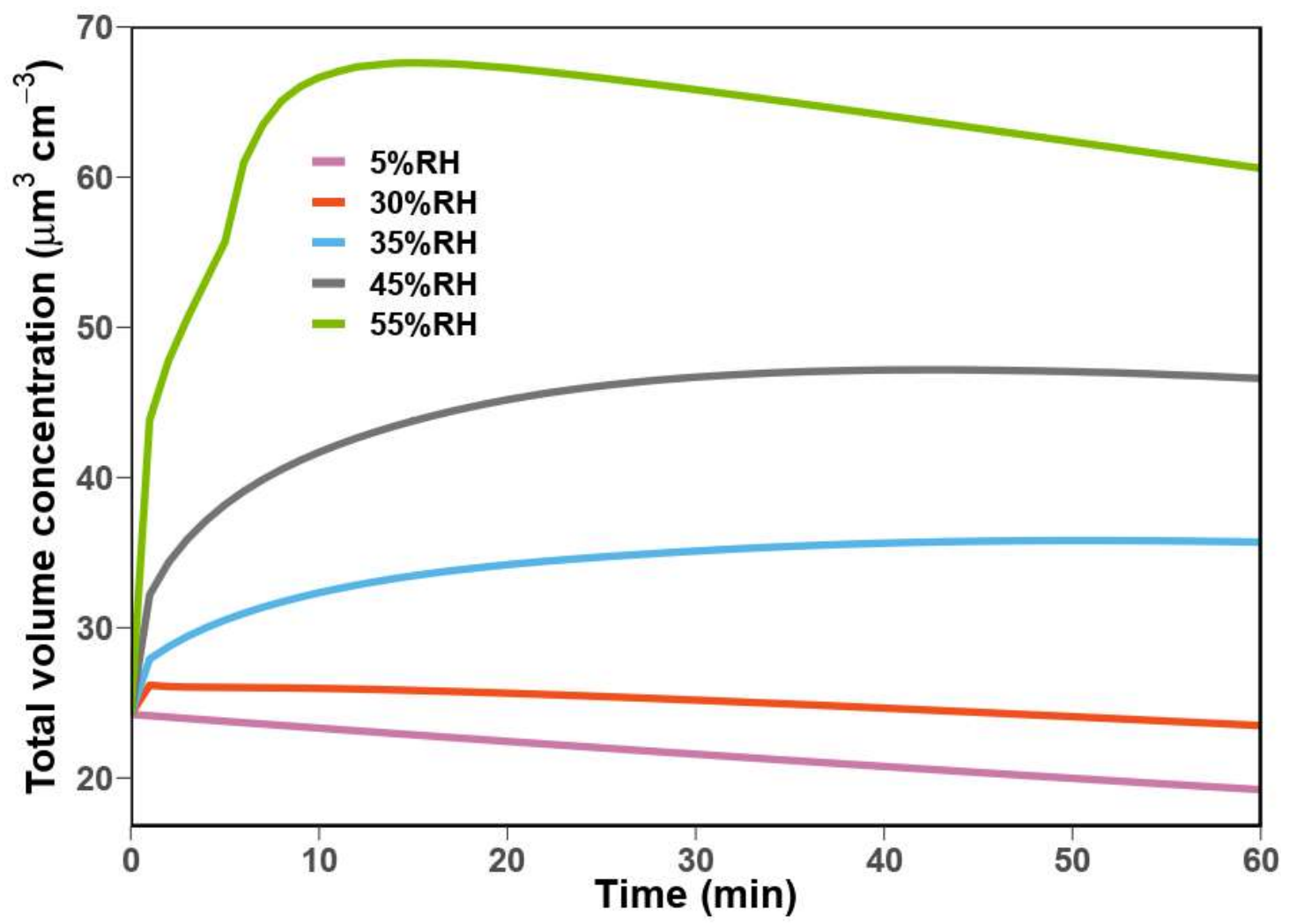

Figure S3. Simulated aerosol volume concentrations $\left(\mu \mathrm{m}^{3} \mathrm{~cm}^{-3}\right)$ integrated for all size bins using different relative-humidity dependent $H_{\mathrm{org}} D_{\mathrm{org}}\left(\mathrm{M} \mathrm{atm}^{-1} \mathrm{~cm}^{2} \mathrm{~s}^{-1}\right)$ values. 


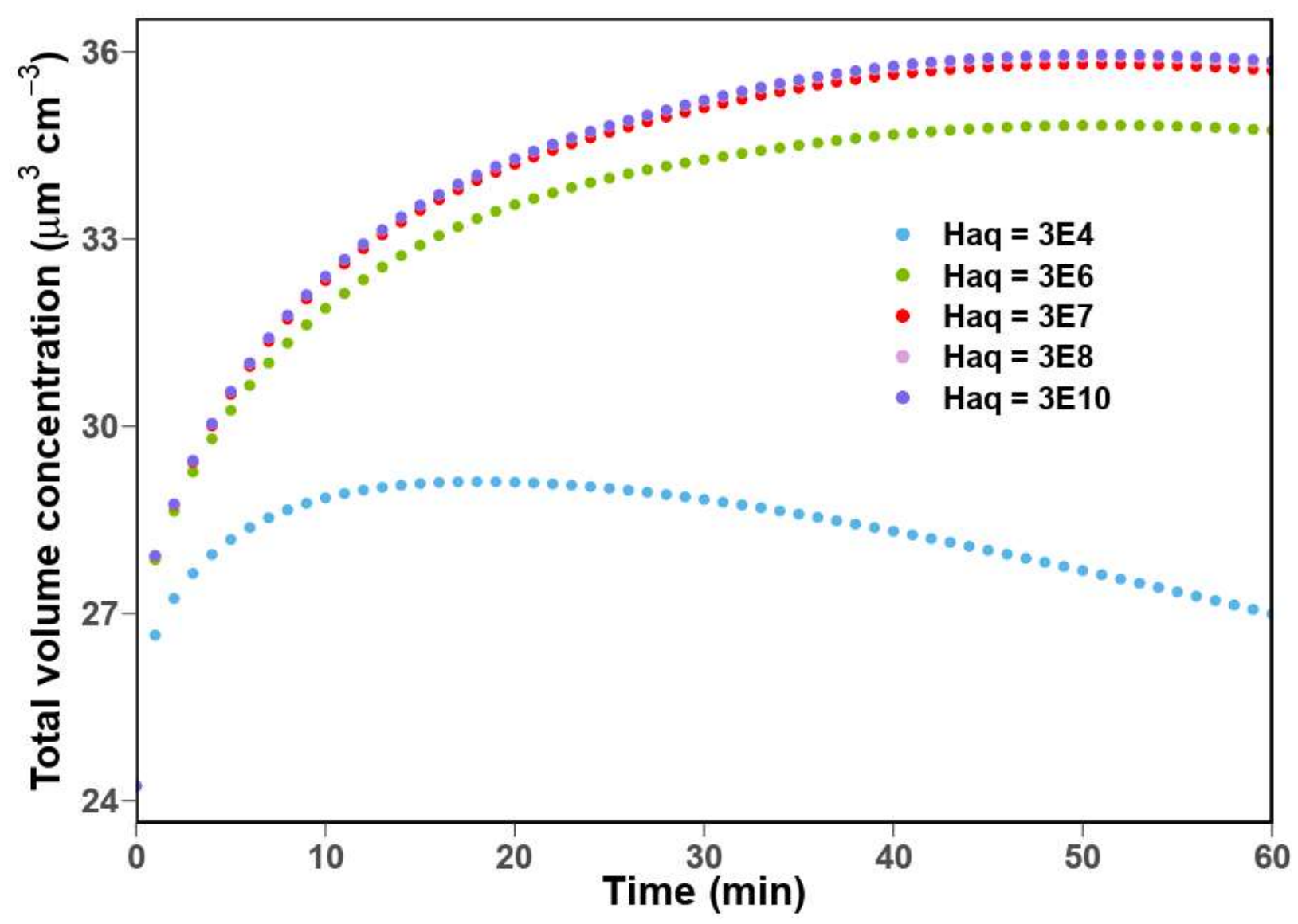

Figure S4. Simulated aerosol volume concentrations $\left(\mu \mathrm{m}^{3} \mathrm{~cm}^{-3}\right)$ integrated for all size bins using different values of Henry's Law coefficient $\left(\mathrm{M} \mathrm{atm}^{-1}\right)$ of IEPOX in the inorganic layer $\left(H_{\mathrm{aq}}\right)$. 


\section{d) Aerosol wall loss}

The loss of particle to the chamber wall was represented as first-order process in the model, and the wall loss coefficient $k_{\text {wall }}$ was determined from an exponential fit of the 2-hour SMPS-measured particle number concentrations after IEPOX injection, resulting in $k_{\text {wall }}$ of $6.47 \mathrm{E}-5 \mathrm{~s}^{-1}$. It is found that after particle wall loss corrections, the model reproduces both time evolution of total number concentration and size distribution of aerosols during the experiment (Fig. S5).
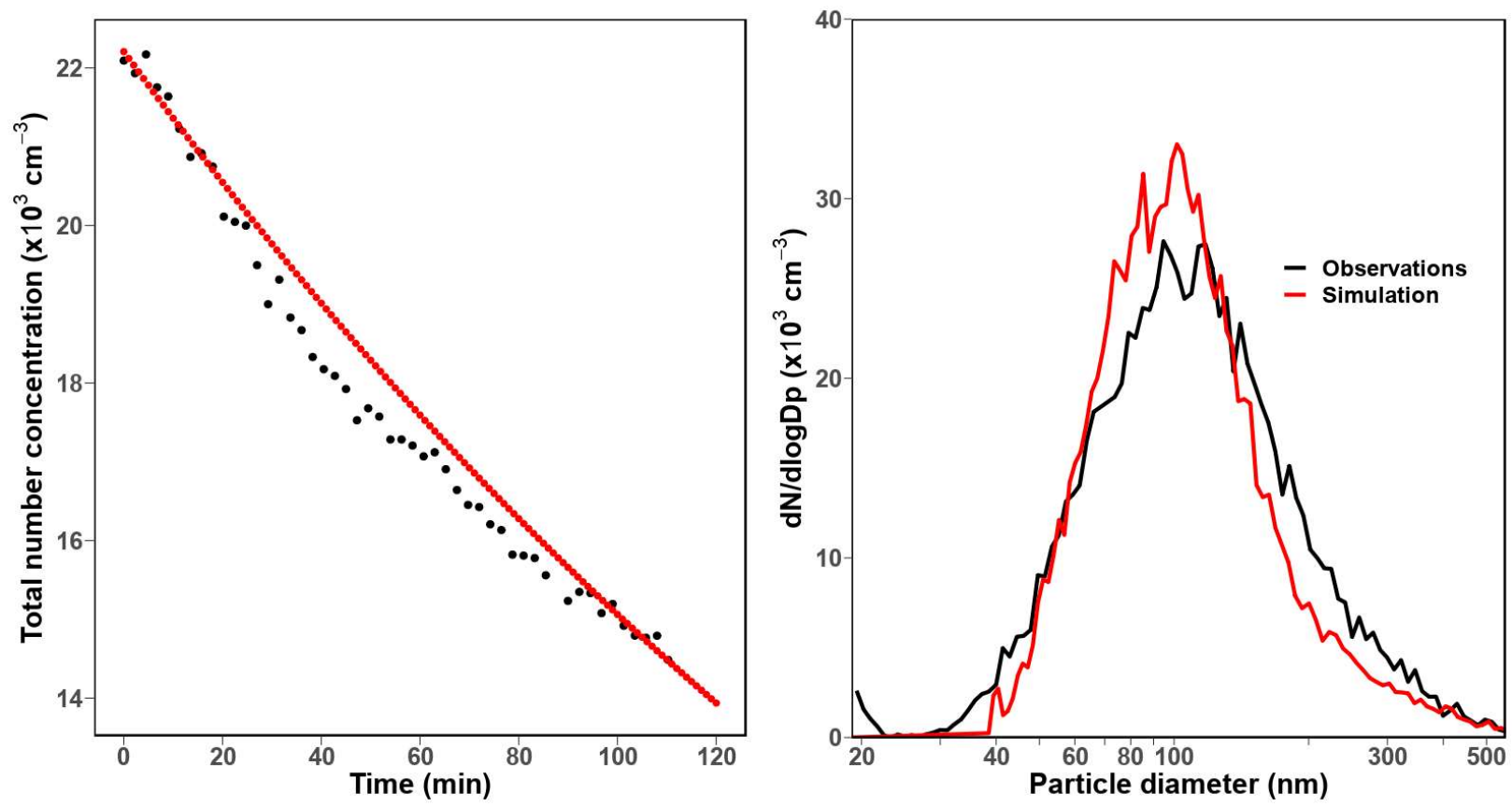

Figure S5. (a) Time series of observed (black) and simulated (red) total number concentrations, and (b) observed and simulated number size distribution (dN/dlogDp) after 2 hours. 


\section{S.2 Results}

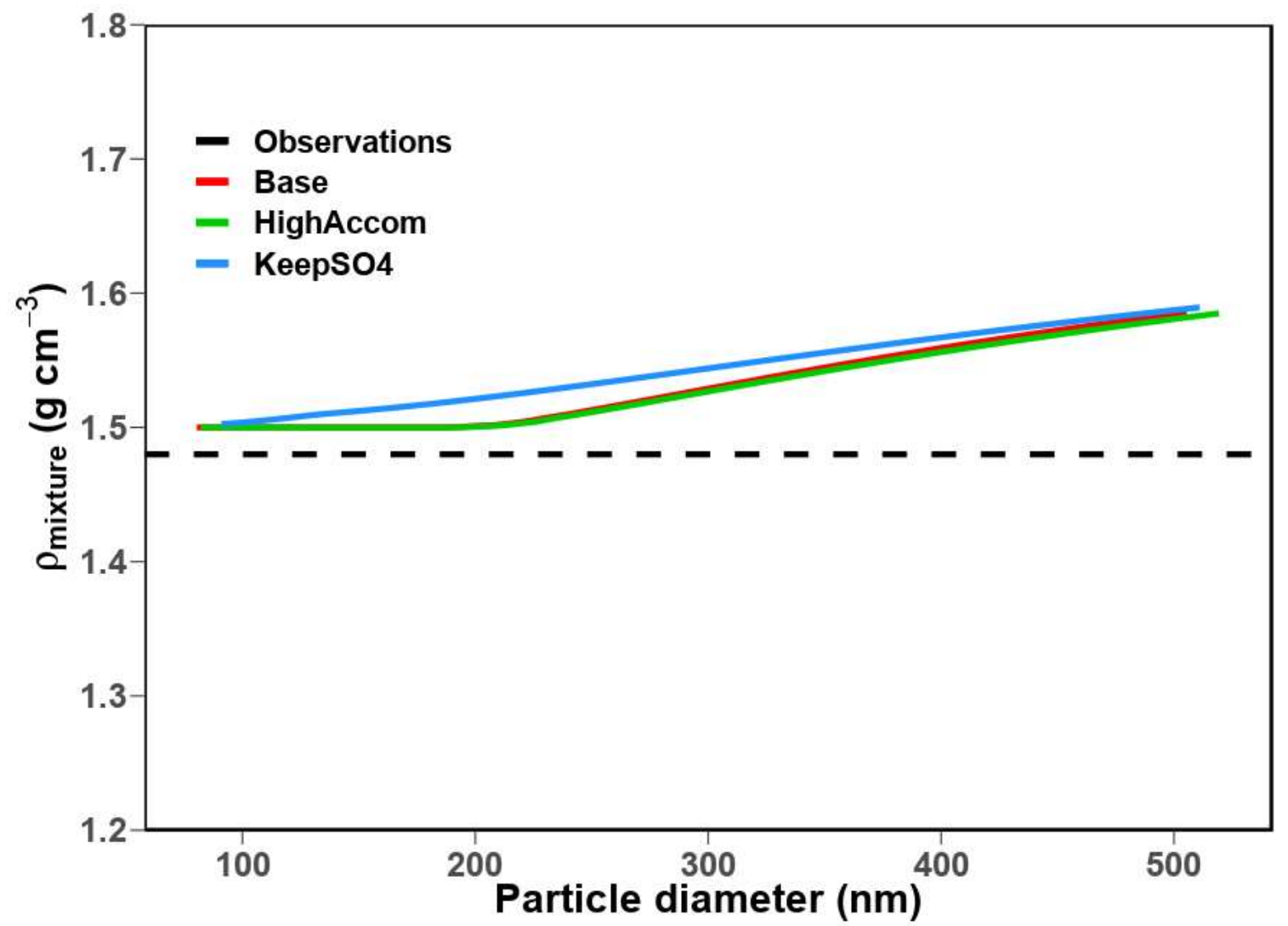

Figure S6. Size distribution of final aerosol density from observations (black dashed line) and simulations (color solid lines). 


\section{References}

1. Riva, M.; Bell, D. M.; Hansen, A.-M. K.; Drozd, G. T.; Zhang, Z.; Gold, A.; Imre, D.; Surratt, J. D.; Glasius, M.; Zelenyuk, A., Effect of organic coatings, humidity and aerosol acidity on multiphase chemistry of isoprene epoxydiols. Environ. Sci. Technol. 2016, 50 (11), 55805588.

2. Budisulistiorini, S. H.; Nenes, A.; Carlton, A. G.; Surratt, J. D.; McNeill, V. F.; Pye, H. O. T., Simulating aqueous-phase isoprene-epoxydiol (IEPOX) secondary organic aerosol production during the 2013 Southern Oxidant and Aerosol Study (SOAS). Environ. Sci. Technol. 2017, 51 (9), 5026-5034.

3. Zaveri, R. A.; Easter, R. C.; Wexler, A. S., A new method for multicomponent activity coefficients of electrolytes in aqueous atmospheric aerosols. J. Geophys. Res.: Atmos. 2005, 110 (D2).

4. Zaveri, R. A.; Easter, R. C.; Fast, J. D.; Peters, L. K., Model for Simulating Aerosol Interactions and Chemistry (MOSAIC). J. Geophys. Res.: Atmos. 2008, 113 (D13).

5. Wexler, A. S.; Clegg, S. L., Atmospheric aerosol models for systems including the ions $\mathrm{H}+$, $\mathrm{NH} 4+, \mathrm{Na}+, \mathrm{SO} 42-, \mathrm{NO} 3-, \mathrm{Cl}-, \mathrm{Br}-$, and H2O. J. Geophys. Res.: Atmos. 2002, 107 (D14), ACH-14.

6. Eddingsaas, N. C.; VanderVelde, D. G.; Wennberg, P. O., Kinetics and products of the acid-catalyzed ring-opening of atmospherically relevant butyl epoxy alcohols. J. Phys. Chem. A 2010, 114 (31), 8106-8113.

7. Nguyen, T. B.; Coggon, M. M.; Bates, K. H.; Zhang, X.; Schwantes, R. H.; Schilling, K. A.; Loza, C. L.; Flagan, R. C.; Wennberg, P. O.; Seinfeld, J. H., Organic aerosol formation from the reactive uptake of isoprene epoxydiols (IEPOX) onto non-acidified inorganic seeds. Atmos. Chem. Phys. 2014, 14 (7), 3497-3510.

8. $\quad$ Riedel, T. P.; Lin, Y. H.; Zhang, Z.; Chu, K.; Thornton, J. A.; Vizuete, W.; Gold, A.; Surratt, J. D., Constraining condensed-phase formation kinetics of secondary organic aerosol components from isoprene epoxydiols. Atmos. Chem. Phys. 2016, 16 (3), 1245-1254. 